\title{
KNOWLEDGE, PERCEPTION AND CERVICAL CANCER SCREENING PRACTICES AMONG FEMALE NURSES WORKING IN HEALTHCARE FACILITIES IN LAGOS STATE, NIGERIA
}

\section{Okesiji Idowu Omotunde $^{1}$ and Professor Amosu Ademola M. ${ }^{2}$}

\author{
${ }^{1}$ Department of Public Health, Babcock University, Illian-Remo. Ogun State. Email: \\ idowuokesiji@gmail.com
}

${ }^{2}$ Department of Public Health, Babcock University, Illian-Remo. Ogun State. Email: ademolaamosu@babcock.edu.ng

Cite this article:

Okesiji I.O., Amosu A.M. (2021), Knowledge,

Perception and Cervical Cancer Screening Practices among Female Nurses Working in Healthcare Facilities in Lagos State, Nigeria. International Journal of Public Health and Pharmacology 1(1), 74-92. DOI: 10.52589/IJPHPVBJ0YBPJ.

\section{Manuscript History}

Received: 23 May 2021

Accepted: 22 June 2021

Published: 25 June 2021

Copyright $(9) 2020$ The Author(s). This is an Open Access article distributed under the terms of Creative Commons AttributionNonCommercial-NoDerivatives 4.0 International (CC BY-NC-ND 4.0 ), which permits anyone to share, use, reproduce and redistribute in any medium, provided the original author and source are credited.
ABSTRACT: Background: Cervical cancer, the $2^{\text {nd }}$ most common form of cancer worldwide, is largely preventable. It occurs more in sexually active and menopausal women of which nurses as the largest group of healthcare giver have an important role to play in early detection, prevention, screening and management. Therefore, nurses' knowledge, perception and cervical cancer screening practices in Lagos State are sought. Methods: A descriptive cross-sectional design, using a multistage sample technique to select 420 nurses and a semi-structured questionnaire (Cronbach Alpha coefficient range: 0.82- 0.84) research tool was used. The response rate was $96.9 \%$. IBM SPSS version 23 was used in data analysis. The confidence level was 0.05 Results: Findings revealed a mean age of $37.7 \pm 9.5$ years, $2 / 3$ of total respondents (66.8\%) had BNSc, nearly half, 227(55.8\%) had good knowledge of cervical cancer screening and less than half $197(48.4 \%)$ had a high perception of cervical cancer screening. The majority $312(76.7 \%)$ of the respondents had low cervical cancer screening practices. Respondents' knowledge of cervical cancer and perception of cervical cancer screening relationship was significant $(\mathrm{r}=-0.19, p=0.000)$. Also, respondents age $\left(X^{2}=11.49, p=0.02\right)$; marital status $\left(X^{2}=10.17\right.$; $p=0.03)$; and respondents' ethnicity $\left(\mathrm{X}^{2}=10.11 ; p=0.02\right)$, were significant to their cervical cancer screening practices. Contrarily, respondent's religion $\left(\mathrm{X}^{2}=3.35 ; p=0.09\right)$, and level of education $\left(\mathrm{X}^{2}=0.88 ; p=0.64\right)$ were not significantly related to cervical cancer screening. Conclusion: Study revealed that respondents had moderately high knowledge, moderate perception of cervical cancer screening but low screening practices. Therefore, nurses should be further resourced in promotional activities and programs through in-service training in providing informative awareness education about cervical cancer screening.

KEYWORDS: Cervical Cancer 1, Nurses Knowledge and Perception 2, Screening Practices 3. 


\section{INTRODUCTION}

The Society of Gynaecology and Obstetrics of Nigeria (SOGON) described cervical cancer as a malignant tumour of the uterine cervix that can be identified with the presence of a lesion affecting the lowermost part of the uterus. However, it is highly preventable by Papillomavirus screening (Pap smear) and Human Papillomavirus (HPV) vaccination. (Akinola, Aimaku, Ezechi, Fasuba. 2018). Cervical cancer has remained a major public health burden in many low- and middle-income countries worldwide, where it ranks as either the most common or the 2nd most common cause of cancer-related deaths in females (Bray, Ferlay, Soerjomataram, Siegel, Torre, \& Jemal, 2018). Globally, in 2018, it ranked as the 4th most common cancer and cause of cancer-related deaths in women with an estimated 570,000 new cases and 311,000 deaths (Bray et al. 2018). Africa has the highest incidence and mortality rates of cervical cancer in the world, which is approximately ten times higher than that seen in western countries (Bray et al. 2018). In Nigeria, cervical cancer is the 2 nd most common cancer in the country and in women, where it accounts for $16.4 \%$ of all female malignancies in 2020 , with estimated new cases of 12,075 (GLOBOCAN,2020).

Current evidence-based recommendation for cervical cancer screening supports the use of cytology screening alone every 3 years, screening for high-risk human papillomavirus (HPV) alone every 5 years or co-testing with both cytology and HPV screening every 5 years (WHO,2013). Most of the cytology screening centres in Nigeria are located in the secondary and tertiary health facilities in the urban areas (Sowemimo, Ojo \& Fasubaa, 2017). In areas, where cytology-based screening is not feasible, the use of the "see and treat" technique with visual inspection with acetic acid (VIA) or HPV testing if available followed by cryotherapy or loop electrosurgical excision procedure is advocated (WHO, 2013).

Knowledge about cancer of the cervix and its screening is important in screening uptakes. Also, women with low levels of knowledge about cervical cancer and its prevention are less likely to access screening services (Nwozor \& Oragudosi, 2013; Oche et al., 2013). Previous studies done among female health workers have shown good knowledge of cervical cancer; however, cervical cancer screening attendance rates are still far from satisfactory in most countries (Oche et al, 2013; Nwobodo \& Malami 2005; Udigwe, 2006).

The key aspect of its prevention is the detection of the premalignant form by cervical screening; it is also one type of cancer that can be prevented and cured if detected early enough (Arevian, Noureddine \& Kabakian, 2006). The screening for cervical cancer has been shown to be relatively effective in detecting precancerous and early cancerous cervical lesions (Adegboyega, Aleshire, \& Linares, 2017).

\section{LITERATURE/THEORETICAL FRAMEWORK}

Cervical cancer is the second most common cancer and the most common malignancy of the female genital tract in developing countries. (Ifemelumma, Anikwe, Okorochukwu, Onu, Obuna, Ejikeme, \& Ezeonu, 2019). It was estimated that 528,000 newly diagnosed cases were recorded globally in 2012, and about 270,000 cervical cancer deaths were recorded in 2016. (Ferley, Soerjomataram, Dikshit, Eser, Mathers, \& Rebelo, 2015). However, it is a potentially preventable disease if appropriate screening and prophylaxis strategies were employed. (Heena, Durrani, Alfayyad, Riaz, Tabasim, Parvez \& Abu- Shaheen, 2019). Various studies 
have confirmed that Cervical cancer occurs as a sexually transmitted infection with a higher prevalence amongst women who have multiple sexual partners, those whose partners have many sexual partners, and those who are sexually active. With the presence of the causative virus, (HPV), it is seriously worrisome as all sexually active women are at risk of developing cervical cancer as they age. (Aldohaian, Alshammari, \& Arafah (2019).

\section{Prevalence of Cervical Cancer}

Globally, the incidence of cervical cancer is not evenly distributed between the developed countries and the less-developed countries because cervical cancer incidence rates and deaths in well-developed countries have progressively reduced due to awareness, screening programmes and vaccination (Zheng \& Ding 2018). In addition, it was projected that 500,000 deaths any occur globally by 2030, of which $85 \%$ would occur in developing countries. (Nwobodo and Ba-Break 2015.) According to Zheng \& Ding. (March 21, 2018, in China, cervical cancer is the second most common form of female cancer and the third leading cause of death among young women of childbearing (14 to 44years) age with an estimated $25 \%$ of the world's annual cervical cancer deaths. In Nigeria, according to Ifemelumma et al $(2019)$, the annual National incidence of cancer of the cervix is 250/100,00 and approximately 8,000 deaths. This is similar to occurrences of cervical cancer disease in the majority of developing countries in Sub-Saharan Africa which is attributable to lack of effective cervical screening programmes, poor knowledge, negative health-seeking behaviour of the populace, and lack of standard policy or protocol for cervical screening as compared to the developed countries where established screening programmes have contributed about $70-90 \%$ incidence reduction (Arulogun \& Maxwell 2012).

\section{Conceptual Model}

\section{Health belief model as a framework for predicting behaviours}

The health belief model was originally developed in the 1950s by a social psychologist in the U.S Public Health Service to explain the widespread failure of people to participate in programs to prevent and detect disease. Later, the model was extended to study peoples' responses to symptoms and their behaviours in response to diagnosed illness, especially on adherence to medical regimens (Glanz et al., 2008). This model aims to explain preventive health behaviours rather than behaviours in times of illness (Ben-Natan \& Adir, 2009). Major health behaviours emphasized by the Health Belief Model focus on preventing the exposure of diseases at their asymptomatic stage (Lee, 2000). The Health Belief Model contains several primary concepts that predict why people will take action to prevent, screen for, or control disease conditions. Thus, this model assumes that health behaviours are motivated by five elements of perceived susceptibility, perceived seriousness, perceived benefits and perceived barriers to behaviour, cues to action and most recently factor of perceived self-efficacy (Champion \& Skinner, 2008).

The health belief model (HBM) has been tested, translated and utilised to study women in different cultures on the globe (Albolfotouh, BaniMustafa, Mahfouz, Al-Assiri, Al_juhani \& Alaskar. 2015) and it focuses on personal health-related behaviour for futuristic prediction of actions (Yakout, Moawed \& Gemeay. 2019). For this study, the HBM concept would be utilized to popularise nurses' knowledge, perception and cervical screening practices of nurses working in Lagos State hospitals. 
Table of Health Belief Model Concept on knowledge, Perception and cervical Screening Practices of Nurses.

\begin{tabular}{|l|l|}
\hline Perceived Susceptibility & $\begin{array}{l}\text { Nurses' personal or self-assessment of chances or risk of } \\
\text { developing cervical cancer is essential having belonged } \\
\text { within the childbearing age group, pre-menopausal or } \\
\text { being sexually active or a potential carrier of human } \\
\text { papillomavirus. }\end{array}$ \\
\hline Perceived Severity & $\begin{array}{l}\text { As a health worker, individual judgement of the severity of } \\
\text { cervical cancer as a chronic and deadly disease can } \\
\text { contribute significantly to the knowledge and practices on } \\
\text { screening uptakes. }\end{array}$ \\
\hline Perceived Benefits & $\begin{array}{l}\text { Personal conviction of nurses on whether it will be a better } \\
\text { idea to adopt a new behaviour on cervical screening } \\
\text { against cancer, or opt for vaccination other than what was } \\
\text { previously practised. This can be improved by motivation } \\
\text { though this may not translate to action. Improvement may } \\
\text { invariably occur in cases where programmes are made } \\
\text { specifically for nurses only. }\end{array}$ \\
\hline Perceived Barrier & $\begin{array}{l}\text { Personal opinion of nurses on what can impede them from } \\
\text { assessing and adopting the new behaviour that is linked to } \\
\text { improved health. These could be in the form of feeling } \\
\text { embarrassed about the procedure or feeling uncomfortable } \\
\text { due to perceived lack of privacy, financial concern, and } \\
\text { fear of pain or lack of social support. }\end{array}$ \\
\hline Cues to action & $\begin{array}{l}\text { Identification, awareness and uptake of factors that can } \\
\text { trigger behaviour change such as health education, health } \\
\text { insurance package and incentives for nurses who embark } \\
\text { on cervical cancer prevention practices. }\end{array}$ \\
\hline $\begin{array}{l}\text { Personal belief in the ability to do something comes if } \\
\text { there is reinforcement such that screening becomes a } \\
\text { routine healthcare measure. }\end{array}$ \\
\hline and
\end{tabular}

\section{METHODOLOGY}

Study Area. The study area was Lagos State healthcare facilities comprising one Teaching Hospital (LUTH), three General Hospitals (General Hospitals in Badagry, Alimosho and Lagos Island) and 12 affiliated Primary Health Centres.

Study Design. This was a descriptive cross-sectional study.

Sample size. The sample size $\left(\mathrm{N}_{0}\right)$ was calculated using

$$
\underline{\mathrm{Z}^{2}([\mathrm{P}(1-\mathrm{P})]}
$$

$\mathrm{d}^{2}$. 
Where $\mathrm{Z}^{2}$ is a constant $=1.96$

$$
\mathrm{N}_{0}=\left(\underline{1.96)^{2} \times 0.5 \times 0.5} .\right.
$$

$$
(0.05)^{2}
$$

$\mathrm{N}_{0}=384.16$

$10 \%$ loss to attrition was added to the sample size, i.e, $384+38=422$. Therefore, approximately the sample size was 420 .

\section{Sampling Technique and Data Collection.}

The multistage sampling technique was used to select participants for the study.

Stage one: Simple random sampling to pick one out of the two tertiary healthcare institutions. Then, the Proportionate sampling technique was used to select the number of participants from the selected hospitals. (see table 1.1). Then, three (3) General Hospitals were selected by random numbers. In total, four hospitals were surveyed. Also, from each GH community, four (4) affiliated Primary Healthcare Centres were selected for data collection based on convenience of the location of PHCs and accidental sampling technique for the respondents

Stage two: Stratified sampling technique was also used to select from existing departments in the hospitals which served as the strata, and a quota was calculated from each of the departments in the hospitals, based on the number of nurses in these departments.

Then simple random sampling (balloting) was applied to draw the 420 participants in accordance with the population of nurses per hospital and PHCs.

Table 1. Table of sample size determination.

\begin{tabular}{|l|l|}
\hline Tertiary hospital $($ LUTH) & General hospitals \\
\hline $532 \times 420=74.6$ & $\frac{2461}{2993} \times 420=345$ \\
2993 & Badagry $107 \div 416 \times 345=89$ \\
& Lagos $129 \div 416 \times 345=107$ \\
& Alimosho $180 \div 416 \times 345=149$ \\
\hline
\end{tabular}

The selection for PHCs was done by convenience sampling technique

Badagry distribution went to GH Badagry 61, 7 instruments each for Marina, Ajara post, Ajara Topa, and Apa

Alimosho distribution went to GH Alimosho 105, 11 instruments each for Aregbesola, AyoboIpaja, Akinyele and Bola Tinubu.

GH Lagos distribution went to GH Lagos 75, then 8 instruments each for Agarawu, Oke Arin, Idumota, and Jankara. 
Data Analysis. The data obtained were coded and analysed using Statistical Package for Service Solution (SPSS) version 23.0. Data obtained were reclassified for ease of analysis and computing for frequency distributions, mean, standard error of means and standard deviation. Correlation and Chi-Square analysis were conducted to give statistical responses to the research questions and hypotheses.

\section{Ethical Consideration.}

Ethical clearance was obtained from Babcock University Health Research and Ethics Committee (BUHREC) of Babcock, LUTH, PHC Board and the General Hospital Boards. Participants were offered informed consent, and information stating their right to participate in the study at will and also the right to withdraw from the research at any point in time.

\section{RESULTS/FINDINGS}

The retrieval rate of the research instrument was $96.9 \%$, socio-demographic characteristics of the respondents are shown in table 4.1. The respondent's ages ranged from 19 to 67years with a mean of $37.7 \pm 9.5$ years. The ages of the majority 147(43.0\%) of the respondents are between ages 29 to 38 years. Most 301(74\%) of the respondents were married and the majority $349(85.7 \%)$ were Christians. The Yoruba's 290(71.3\%) were the predominant ethnic group. More than half 272(66.8\%) of the respondents had their first degree in nursing science. (See Table 2).

Table 2. Socio-demographic Characteristics of the Respondents

\begin{tabular}{|l|l|l|}
\hline Socio-demographic variables for consideration & \multicolumn{2}{|c|}{$\begin{array}{c}\text { Respondents in this study; } \\
\text { N=407 }\end{array}$} \\
\cline { 2 - 3 } Age (in years) $\mathbf{x} \mathbf{~ 3 7 . 7 ( 0 . 4 7 ) \pm 9 . 4 8}$ & & \\
19-28 & 73 & 17.9 \\
$29-38$ & 175 & 43.0 \\
$39-48$ & 87 & 21.4 \\
$49-58$ & 70 & 17.2 \\
59-68 & 2 & 0.5 \\
\hline Marital Status & & \\
Single & 91 & 22.4 \\
Married & 301 & 74.0 \\
Separated & 5 & 1.2 \\
Widowed & 8 & 2.0 \\
Divorced & 2 & 0.5 \\
\hline Religion & & \\
Christian & 349 & 85.7 \\
Islam & 58 & 14.3 \\
\hline
\end{tabular}




\begin{tabular}{|l|l|l|}
\hline Ethnicity & & \\
Yoruba & 290 & 71.3 \\
Igbo & 92 & 22.6 \\
Hausa & 7 & 1.7 \\
Others & 18 & 4.4 \\
\hline Level of education & & \\
Diploma in Nursing & 120 & 29.5 \\
B.Sc. Nursing & 272 & 66.8 \\
M.Sc. & 15 & 3.7 \\
\hline
\end{tabular}

\section{Respondents Knowledge Cervical Cancer and Cervical Screening}

The majority of the respondents, 384(94.3\%), knew that cancer is a disease. Most 324(79.6\%) of the respondents knew that cervical cancer affects women, while 246(60.4\%) knew that cervical cancer affects only adults. The majority of the respondents, 358(88.0\%), reported that the virus is one of the causes of cervical cancer. Virtually all 390(95.8\%) of the respondents knew that human papillomavirus is responsible for developing cervical cancer. The respondents stated the following as the risk factors for cervical cancer early age of sexual debut 216(19.8\%), having multiple sexual partners 317(29.1\%), increase parity $133(12.2 \%)$, immunosuppression 192(17.4\%) and genital infection 235(21.5\%). The majority of the respondents knew the symptoms of cervical cancer as abnormal menstrual bleeding $283(30.8 \%)$, bleeding between menstrual period 266(27.7\%) and unpleasant vaginal discharge $258(13.5 \%)$. Most 354(28.0\%) of the respondents reported that the human papillomavirus is one of the main causes of cervical cancer. (See, Table 3). Many of the respondents stated the following as the screening method for cervical cancer; pap smear 345(50.4\%), Visual inspection with acetic acid 195(28.5\%) and colposcopy $145(21.1 \%)$. About a quarter of respondents, 114(28\%), knew that cervical cancer screening is every 3 years. The respondents reported that cervical cancer can be prevented through education $248(17.5 \%)$, vaccination 240(21.0\%), screening 298(16.9\%), avoidance of multiple sexual partners 301(21.2\%), early diagnosis 244(17.2\%) and short-term use of contraceptive pills 88(6.2\%) (See, Table 4)

Furthermore, respondent's level of knowledge measured on a 23-point rating scale showed that the respondents scored a mean of $15.68 \pm 3.65$ translated to a level of knowledge prevalence of $68.2 \%$. The proportion of the respondents with good knowledge was $227(55.8 \%$ ). (See table 4.2.1). One can infer that less than half of respondents had a fair knowledge of cervical cancer since 180(44.2\%) had a fair knowledge of cervical cancer (See Tables 3,4 and 5).

Table 3: Respondents Knowledge of Cervical Cancer

\begin{tabular}{|l|l|l|}
\hline \multirow{2}{*}{ Items } & \multicolumn{2}{l}{ Respondents in this study=407 } \\
\cline { 2 - 3 } & Frequency(n) & Per cent (\%) \\
\hline Cancer is a disease & & \\
Yes & 384 & 94.3 \\
No & 23 & 5.7 \\
\hline Who can be affected by cervical cancer & & \\
Men & 10 & 2.5 \\
Women & 325 & 76.6 \\
All sexes & 70 & 17.2 \\
None & 3 & 0.7 \\
\hline
\end{tabular}




\begin{tabular}{|c|c|c|}
\hline $\begin{array}{l}\text { Age group affected by cervical cancer } \\
\text { Children } \\
\text { Adolescent } \\
\text { Adults } \\
\text { All age groups } \\
\text { Don't know }\end{array}$ & $\begin{array}{l}15 \\
25 \\
246 \\
119 \\
2\end{array}$ & $\begin{array}{l}3.7 \\
6.1 \\
60.4 \\
29.2 \\
0.5\end{array}$ \\
\hline $\begin{array}{l}\text { Causes of cervical cancer } \\
\text { Virus } \\
\text { Fungus } \\
\text { Bacteria } \\
\text { Spiritual factors }\end{array}$ & $\begin{array}{l}358 \\
9 \\
39 \\
1\end{array}$ & $\begin{array}{l}88.0 \\
2.2 \\
9.6 \\
0.2\end{array}$ \\
\hline $\begin{array}{l}\text { Which of the following is responsible for cervical cancer } \\
\text { Diabetes mellitus } \\
\text { HIV } \\
\text { Human papillomaVirus }\end{array}$ & $\begin{array}{l}4 \\
13 \\
390\end{array}$ & $\begin{array}{l}1.0 \\
3.2 \\
95.8\end{array}$ \\
\hline $\begin{array}{l}\text { *Risk factors for cervical cancer } \\
\text { Early sexual debut } \\
\text { Multiple sexual partners } \\
\text { Increased parity } \\
\text { Immunosuppression } \\
\text { Genital infections }\end{array}$ & $\begin{array}{l}216 \\
317 \\
133 \\
192 \\
235\end{array}$ & $\begin{array}{l}19.8 \\
29.0 \\
12.2 \\
17.4 \\
21.5\end{array}$ \\
\hline $\begin{array}{l}\text { *Symptom of cervical cancer } \\
\text { Abnormal menstrual bleeding } \\
\text { Bleeding between menstrual period } \\
\text { Itching of vagina } \\
\text { Unpleasant vaginal discharge }\end{array}$ & $\begin{array}{l}283 \\
255 \\
124 \\
258\end{array}$ & $\begin{array}{l}30.8 \\
27.7 \\
13.5 \\
28.0\end{array}$ \\
\hline $\begin{array}{l}\text { Human papillomavirus is the main cause of cervical } \\
\text { cancer } \\
\text { Yes } \\
\text { No } \\
\text { Do not know }\end{array}$ & $\begin{array}{l}354 \\
44 \\
9\end{array}$ & $\begin{array}{l}87.0 \\
10.8 \\
2.2\end{array}$ \\
\hline
\end{tabular}

* Multiple responses.

Table 4: Respondents Knowledge of Cervical Cancer

\begin{tabular}{|l|l|l|}
\hline \multirow{2}{*}{ Items } & \multicolumn{2}{l|}{ Respondents in } \\
\cline { 2 - 3 } & Frequency(n) & Per cent (\%) \\
\hline *Screening method for cervical cancer & & \\
Pap smear & 345 & 50.4 \\
Visual inspection with acetic acid & 195 & 28.5 \\
Colposcopy & 145 & 21.1 \\
\hline How often should one be screened & & \\
Once a year & 244 & 60.0 \\
Every 3 years & 114 & 28.0 \\
Every 5 years & 38 & 9.3 \\
Once in a lifetime & 1 & 0.2 \\
When the symptom appears & 10 & 2.5 \\
\hline
\end{tabular}




\begin{tabular}{|c|c|c|}
\hline \multicolumn{3}{|l|}{ *Prevention of cervical cancer } \\
\hline Education & 248 & 17.5 \\
\hline Vaccination & 298 & 21.0 \\
\hline Screening & 240 & 16.9 \\
\hline Avoidance of multiple sexual partners & 301 & 21.2 \\
\hline Early diagnosis & 244 & 17.2 \\
\hline Short-term use of a contraceptive pill & 88 & 6.2 \\
\hline
\end{tabular}

Table 5: Level of Respondents Knowledge of Cervical Cancer/ Screening

\begin{tabular}{|l|l|l|l|l|}
\hline \multirow{2}{*}{ Items } & \multicolumn{3}{|l|}{ Measured on a 23-Point rating scale } & \\
\cline { 2 - 5 } & Frequency(n=407) & $\begin{array}{l}\text { Percentage } \\
(\%)\end{array}$ & $\underline{x}($ SE) & Prevalence \\
\hline Fair & 180 & 44.2 & $15.86(0.18) \pm 3.65$ & $68.2 \%$ \\
\hline Good & 227 & 55.8 & & \\
\hline
\end{tabular}

\section{Respondents Perception of Cervical Cancer and screening practices}

More than half 224(55\%) of respondents strongly agree that cancer of the cervix is likely to result in serious health complications. But less than half $185(45.5 \%)$ of the respondents strongly disagree that there is no serious risk of cancer of the cervix if they did not get screened. More than half 229(56.3\%) of the respondents strongly disagreed that they had not thought of cancer of the cervix as a serious health condition that requires serious medical attention. Less than half $164(40.3 \%$ ) of the respondents strongly agree that cervical cancer is preventable. Less than half $180(44.2 \%)$ of the respondents agreed that cervical cancer can be cured $66(16.2 \%)$. A little less than a quarter, 100(24.6\%) of the respondents strongly disagree that poor personal hygiene causes cervical cancer. Slightly above half 206(50.6\%) of the respondents strongly disagree that they will get cancer of the cervix in future. Above a quarter 102(25.1\%) of the respondents strongly disagree that if they did not get screened for cervical cancer, they were at risk of developing cervical cancer. Less than half 194(47.7\%) of the respondents strongly disagree that keeping multiple sexual partners does not matter in the prevention of cancer of the cervix.

More than half $239(58.7 \%)$ of the respondents strongly agree that getting screened will help to detect changes to the cervix before they develop into cancer. Slightly above half 204(50.1) of the respondents strongly agree that getting screened will make them know if they are healthy. Less than half $171(42.0 \%)$ of the respondents strongly agree that early detection of cervical cancer makes it curable. Less than half $180(44.2 \%)$ of the respondents strongly agree that screening is effective in reducing the incidence of cervical cancer. Almost half 203(49.9\%) of the respondents strongly disagree that they did not know about screening. Less than half $128(31.4 \%)$ of the respondents strongly disagree that they perceive the high cost of screening as a barrier to screening. Above a quarter 124(30.5\%) of the respondents disagree that they perceived the unavailability of screening centres as a barrier to screening. Few 26(6.4\%) of the respondents strongly agree that their partner does not agree with the screening. Less than 
half $145(35.6 \%)$ of the respondents disagree that they feel shy due to the procedure (See, Tables $6,7)$.

In addition, respondent's measure of perception on a 54-point rating scale showed that the respondents scored a mean of $35.75 \pm 5.89$ translated to a level of perception prevalence of 66.2 $\%$. The proportion of the respondents with high perception was $197(48.4 \%)$. One can infer that more than half of the respondents had a moderate perception of cervical cancer since only 197(48.4.2\%) had a high perception of cervical cancer (See, Tables 6 and 7).

Table 6. Respondents Perception of Cervical Cancer and Screening Practices

\begin{tabular}{|c|c|c|c|c|}
\hline & & & $\mathbf{N}=$ & 407 \\
\hline Items & $\begin{array}{l}\text { Strongly } \\
\text { agree } \\
\text { F }(\%)\end{array}$ & $\begin{array}{l}\text { Agree } \\
\text { F (\%) }\end{array}$ & $\begin{array}{l}\text { Disagree } \\
\text { F }(\%)\end{array}$ & $\begin{array}{l}\text { Strongly } \\
\text { disagree } \\
\text { F }(\%)\end{array}$ \\
\hline $\begin{array}{l}\text { I think that cancer of the cervix is likely to } \\
\text { result to serious health complications }\end{array}$ & $* 224(55)$ & $119(29.2)$ & $40(9.8)$ & $24(5.9)$ \\
\hline $\begin{array}{l}\text { I am inclined to believe that there is no serious } \\
\text { risk of cancer of the cervix if I do not get } \\
\text { screened }\end{array}$ & $0(0.0)$ & $50(12.3)$ & $172(42.3)$ & $185(45.5)^{*}$ \\
\hline $\begin{array}{l}\text { I have not thought of cancer of the cervix as a } \\
\text { serious health condition that requires serious } \\
\text { medical attention }\end{array}$ & $27(6.6)$ & $38(9.3)$ & $113(27.8)$ & $229(56.3)^{*}$ \\
\hline I think cervical cancer is preventable & $* 164(40.3)$ & $183(45.0)$ & $31(7.6)$ & $29(7.1)$ \\
\hline I think cervical cancer be cured & $* 66(16.2)$ & $180(44.2)$ & $121(29.7)$ & $40(9.8)$ \\
\hline $\begin{array}{l}\text { I think poor personal hygiene causes cervical } \\
\text { cancer }\end{array}$ & $38(9.3)$ & $132(32.4)$ & $137(33.7)$ & $100(24.6)^{*}$ \\
\hline $\begin{array}{l}\text { It is likely that I will get cancer of the cervix in } \\
\text { future }\end{array}$ & $* 16(3.9)$ & $34(8.4)$ & $151(37.1)$ & $206(50.6)$ \\
\hline $\begin{array}{l}\text { If I do not get screened for cervical cancer, I } \\
\text { am at risk of developing cervical cancer }\end{array}$ & $* 35(8.6)$ & $124(30.5)$ & $146(35.9)$ & $102(25.1)$ \\
\hline $\begin{array}{l}\text { Keeping multiple sexual partners does not } \\
\text { matter in the prevention of cancer of the cervix }\end{array}$ & $45(11.1)$ & $46(11.3)$ & $122(30.0)$ & $194(47.7)^{*}$ \\
\hline $\begin{array}{l}\text { I think that getting screened will help to detect } \\
\text { changes to the cervix before they develop into } \\
\text { cancer. }\end{array}$ & $* 239(58.7)$ & $113(27.8)$ & $30(7.4)$ & $25(6.1)$ \\
\hline $\begin{array}{l}\text { Getting screened will make me know if I am } \\
\text { healthy }\end{array}$ & $* 204(50.1)$ & $164(40.3)$ & $29(7.1)$ & $10(2.5)$ \\
\hline $\begin{array}{l}\text { Early detection of cervical cancer makes it } \\
\text { curable }\end{array}$ & $* 171(42.0)$ & 191(46.9) & $31(7.6)$ & $14(3.4)$ \\
\hline $\begin{array}{l}\text { I think screening is effective in reducing the } \\
\text { incidence of cervical cancer }\end{array}$ & $* 180(44.2)$ & $150(36.9)$ & $47(11.5)$ & $30(7.4)$ \\
\hline I do not know about screening & $16(3.9)$ & $46(11.3)$ & $142(34.9)$ & $203(49.9)^{*}$ \\
\hline High cost of screening & $40(9.8)$ & $75(18.4)$ & $164(40.3)$ & $128(31.4)^{*}$ \\
\hline Unavailability of screening centre & $16(3.9)$ & $95(23.3)$ & $172(42.3)$ & $124(30.5)^{*}$ \\
\hline My partner does not agree to it & $26(6.4)$ & $57(14.0)$ & $158(38.8)$ & $166(40.8)^{*}$ \\
\hline I feel shy due to the procedure & $32(7.9)$ & $77(18.9)$ & $153(37.6)$ & $145(35.6)^{*}$ \\
\hline
\end{tabular}


Table 7: Level of Respondents Perception of Cervical Cancer/ Screening Practices

\begin{tabular}{|l|l|l|l|l|}
\hline \multirow{2}{*}{ Items } & \multicolumn{3}{|l|}{ Measured on a 54-Point rating scale } \\
\cline { 2 - 5 } & Frequency $(\mathbf{n = 4 0 7})$ & $\begin{array}{l}\text { Percentage } \\
(\boldsymbol{\%})\end{array}$ & $\underline{x}(\mathrm{SE})$ & Prevalence \\
\hline Moderate & 210 & 51.6 & $35.75(0.29) \pm 5.89$ & $66.2 \%$ \\
\hline High & 197 & 48.4 & & \\
\hline
\end{tabular}

\section{Respondents Cervical Cancer Screening Practices}

As shown in Table 8 below, less than half 175(43.0\%) of the respondents had screened for cervical cancer screening. Of those who had a screening for cervical cancer, above quarter $44(25.1 \%)$ had undergone screening three years ago while $26(14.9 \%)$ undergone screening less than a month ago. Less than half $159(39.1 \%)$ of the respondents reported that nurses had reasons for not undergoing cervical cancer screening. The respondents stated the following reasons for nurses', not screening, fear of a positive outcome $92(57.8 \%)$, do not have time $87(54.7 \%)$ and fear of the procedure $65(40.9 \%)$. Furthermore, respondents' cervical cancer screening practices measured on a 6-point rating scale showed that the respondents scored a mean of $1.59 \pm 2.17$ translated to a screening practice prevalence of $26.5 \%$. The proportion of the respondents with low screening was 312(76.7\%) (See Table 9). This translates that the respondents had low screening practices for cervical cancer screening since only $95(23.3 \%)$ had high screening practices.

Table 8: Respondents Cervical Cancer Screening Practices

\begin{tabular}{|c|c|c|}
\hline \multirow[t]{2}{*}{ Items } & \multicolumn{2}{|c|}{$\begin{array}{l}\text { Respondents in this study }=407 \text {, } \\
\qquad N=175, * * N=159\end{array}$} \\
\hline & Frequency(n) & Per cent $(\%)$ \\
\hline $\begin{array}{l}\text { Have you been screened for cervical cancer } \\
\text { Yes } \\
\text { No }\end{array}$ & $\begin{array}{l}175 \\
232\end{array}$ & $\begin{array}{l}43.0 \\
57.0\end{array}$ \\
\hline $\begin{array}{l}\text { When was the last time screening was done } \\
\text { Less than } 1 \text { month ago } \\
3 \text { month ago } \\
\text { Six months ago } \\
1 \text { year ago } \\
3 \text { years ago } \\
\text { Over } 5 \text { years ago }\end{array}$ & $\begin{array}{l}26 \\
22 \\
31 \\
22 \\
44 \\
30\end{array}$ & $\begin{array}{l}14.9 \\
12.6 \\
17.7 \\
12.6 \\
25.1 \\
17.1\end{array}$ \\
\hline $\begin{array}{l}\text { Are there reasons why nurses don't go for c } \\
\text { cancer screening } \\
\text { Yes } \\
\text { No }\end{array}$ & $\begin{array}{l}159 \\
248\end{array}$ & $\begin{array}{l}39.1 \\
60.9\end{array}$ \\
\hline
\end{tabular}




\begin{tabular}{|l|l|l|}
\hline **+Reason for not screening & & \\
It is costly & 29 & 18.2 \\
Do not have time & 87 & 54.7 \\
I am healthy & 39 & 24.5 \\
Cervical cancer screening is painful & 42 & 26.4 \\
Fear of a positive outcome & 92 & 57.8 \\
Fear of the procedure & 65 & 40.9 \\
Lack of husband/partner approval & 27 & 16.9 \\
Not allowed by religion/culture & 12 & 7.5 \\
\hline
\end{tabular}

**+ Multiple responses

Table 9: Level of Respondents Cervical Cancer Practices

\begin{tabular}{|l|l|l|l|l|}
\hline \multirow{2}{*}{ Items } & \multicolumn{3}{l}{ Measured on a 6-Point rating scale } & \\
\cline { 2 - 5 } & Frequency $(\mathbf{n}=\mathbf{4 0 7})$ & $\begin{array}{l}\text { Percentage } \\
(\boldsymbol{\%})\end{array}$ & $\underline{x}(\mathbf{S E})$ & Prevalence \\
\hline Low & 312 & 76.7 & $1.59(0.10) \pm 2.17$ & $26.5 \%$ \\
\hline High & 95 & 23.3 & & \\
\hline
\end{tabular}

\section{DISCUSSION}

The age group of the respondents varied as their ages spanned from 19 to 67 years and their mean age was $37.7 \pm 9.5$ years. This characteristic is similar to the findings of Awodele et al, (2011) who reported similar mean age. The respondents' being Yoruba might be due to the study location being in the South-west region of the country and they are predominantly Yoruba's. Nyaberi and Buziba (2011) reported that women over 30 years were more likely to have been screened for cervical cancer than younger women. There is a significant relationship between marital status and cervical cancer screening practices. This finding corroborates the results of Singh \& Badaya, (2012). This may be because married women may receive more frequent gynaecological care. There is no relationship between the level of education and cervical cancer screening. This finding is similar to the reports of Abotchie \& Shokar (2009) that high education may not necessarily mean a high chance of one seeking screening. However, it is at variance with the findings of Fernández et al (2009). This implies that additional factors must be considered when assessing the relationship between socioeconomic demographic factors and cervical cancer screening.

The findings revealed that the age range of women most affected by cervical cancer as reported by respondents in this study is in line with the findings of Guintoli \& Bristow (2008) where old age was identified as one of the risk factors associated with cervical cancer. Human papillomavirus (HPV) was identified by most of the respondents as being responsible for developing cancer of the cervix which corroborates with the findings of Umukoro \& Makinde (2019). One of the participants in this study attributed the condition to spiritual factors. On the contrary, respondents in another study revealed religious and spiritual factors as causing cervical cancer, with the majority of them using holy water and praying to god as preventive measures (Dulla et al, 2017). The overall level of knowledge among the respondents was 
average as less than half of them had average knowledge. These results are comparable to the findings of Singh and Badaya (2012) where 69\% of staff nurses who participated in their research in India claimed to have some knowledge related to cervical cancer. The findings also affirm Udigwe's (2006) assertions that in any community, trained nurses and midwives constitute a knowledgeable class with regards to medical information and intervention and that nurses are important health personnel that are supposed to educate women on the need for cervical screening. The level of knowledge found in this study was at variance with Shekhar et al (2013) where a majority of the study participants had a low level of knowledge of cervical cancer. In contrast, a Southern Ethiopia study among female health professionals found that the majority of them had a good level of knowledge on cervical cancer (Dulla et al, 2017). Though there are some similarities in socio-demographic data in terms of age, the vast difference in their knowledge level could be due to the level of professional qualifications of the study population in both pieces of research. Whereas the participants in this study are nurses, the study population in the Ethiopian study includes medical doctors and other specialists as well as nurses. This study revealed that respondent's knowledge about cervical cancer has no significant relationship with cervical cancer screening practice; this collaborates with the findings of Oche et al., 2013) in Sokoto stating that there is no relationship between knowledge and cervical screening practice.

The findings of this study revealed that the majority of the respondents had a moderate perception of cervical cancer screening. This result is, however, consistent with the report of Saha, Chaudhury, Bhowmik \& Chatterjee (2010) that respondent's perception towards cervical screening was average. Additionally, the findings of this study revealed that the majority of the respondents think that cancer of the cervix is likely to result in serious health complications while only a few believe that there is a risk involved if not screened. Furthermore, the majority agree that they may likely get cancer of the cervix in the future, meanwhile more than half agree that keeping multiple sexual partners does not matter in its prevention. Almost all the participant agrees that getting screened will help to detect changes to the cervix and subsequently know their status, this was also found in a study done in Sokoto by Oche, Kaoje, Gana \& Ango (2013) which was understandable due to their level of knowledge about the disease and risks involved if the disease is discovered during late pathogenesis stage. It was agreed by the majority that early detection of cervical cancer makes it curable.

The findings of this study revealed that only $43 \%$ had ever screened for cervical cancer. This magnitude of screening practice in this study is inconsistent with several studies such as Awodele et al, (2011) where 12\% of the respondents had screened, and $15.3 \%$ in Tanzania (Urasa and Darj, 2011). In another study done in South-South Nigeria, 18 (11\%) of the women who participated in the survey had undergone screening for cervical cancer (Eze et al 2013). Other studies by Dulla et al, (2017) also showed equally low patronage $11.4 \%$ among health workers. The finding is not encouraging as health workers who should be the role models and know about the disease are not screening enough. This supports the assertion that knowledge on cervical cancer may not necessarily result in screening. Reasons given for non-utilization such as fear of the results and not having time for cervical cancer screening have been documented in earlier studies in Uganda by Mutyaba et al (2006) and Owerri by Ezem, (2007). Younger nurses are not likely to use the service because they may perceive themselves as young, not susceptible and therefore, not bothered about such issues. 


\section{IMPLICATION TO RESEARCH AND PRACTICE}

Cervical cancer is a disease of Public health importance to the female gender with the possibility of high mortality if not detected early for prompt intervention. Nurses, who are the most numbered healthcare delivery workforce and are identified to lack high rates of cervical screening practices should be motivated through Mandatory continuous education programmes on cervical cancer. In practice, cervical cancer screening should be included in routine and preemployment medical examinations.

The nurses with adequate knowledge, perception and Ideal cervical screening practices would be placed in charge.

\section{CONCLUSION}

Cervical cancer has remained a major public health burden in many low- and middle-income countries worldwide, where it ranks as either the most common or the 2 nd most common cause of cancer-related deaths in females (Bray, Ferlay, Soerjomataram, Siegel, Torre, \& Jemal, 2018). Globally, in 2018, it ranked as the 4th most common cancer and cause of cancer-related deaths in women with an estimated 570,000 new cases and 311,000 deaths (Bray et al. 2018). Africa has the highest incidence and mortality rates of cervical cancer in the world, which is approximately ten times higher than that seen in western countries (Bray et al. 2018). In Nigeria, cervical cancer is the 2nd most common cancer in the country and in women, where it accounts for $16.4 \%$ of all female malignancies in 2020, with estimated new cases of 12,075 (GLOBOCAN,2020). Several risk factors have been associated with cervical cancer such as early age at first sexual intercourse, multiple male sexual partners, male sexual partners who have had multiple partners, early age at first birth, multi-party, smoking, long-term use of oral contraceptive pills, and immunosuppressed states (Momenimovahed, \& Salehiniya, 2017). Abnormal vaginal bleeding, foul-smelling vaginal discharge, and contact bleeding are recognized as the major signs of cervical cancer, and in many cases, women with cervical cancer report no symptoms.

The study revealed that the respondents had moderate knowledge and perception of cervical cancer screening. Less than half of the respondents had been screened for cervical cancer. There was a significant relationship between respondents' age, marital status, ethnicity, cervical cancer perception and screening practices. Also, there was no significant relationship between respondents' knowledge and screening practices. Likewise, no significant relationship was found between respondents' perception and their screening practices.

The seriousness and hazards that cancer brings into the lives and existence of sufferers of the disease cannot be quantified. Cervical cancer is a type of cancer limited to and suffered by women and has serious adverse effects on the ability of women to function properly within their sphere as mothers, caregivers and sometimes breadwinners. Nurses due to their daily contact with patients, their relatives, friends and the general public can be viewed as fountains of knowledge. Therefore, it is important that they have the right kind of knowledge and information to disseminate to the public. The study revealed that respondents had moderate knowledge and perception of cervical cancer screening. It is evident from this study that despite the moderate level of awareness of cervical cancer screening, the practice remains low amongst nurses. Therefore, the nurses' health promotion unit should be further resourced to handle 
promotional activities and programs through in-service training in providing informative education to help improve the level of awareness about cervical cancer screening among Nurses in general.

\section{Limitation to the study}

1. The majority of the Nurses presented poor reception to fill the questionnaire despite that they show interest in participating.

2. Confounding variable of having to exclude the Community Health Extension Workers (CHEWs) and Community Health Officers (CHOs) in sample selection.

3. Work schedules (flexi-roster) and routine patient care of the nurses prevented them from devoting prompt attention to attending to the questionnaire.

4. More than half of the participants requested incentives that were not planned for initially.

\section{Conflicts of Interest}

The authors declare that they have no conflict of interest.

\section{Authors' Contribution}

A.M Amosu participated in the study design, manuscript drafting and interpretation of data.

I.O Okesiji participated in the study design, manuscript drafting, data collection and analysis and interpretation of the findings. All the authors approved the manuscript.

\section{Future Research}

In subsequent research on knowledge, perception and cancer screening practices among nurses in Lagos state, it would be necessary to investigate the effect of peer-led and expert-led education on knowledge, perception and cancer screening practices. Furthermore, it would be important to investigate the factors that can lead to high uptakes or low uptakes of cervical screening practices. There is a possibility of investigating other female health care workers in the listed hospital as regards cervical cancer knowledge, perception and screening practices.

\section{REFERENCES}

Abotchie, P. \& Shokar, N. (2009). Cervical cancer screening among college students in Ghana: Knowledge and health beliefs. International Journal of Gynaecological Cancer 19:412-416.

Ackerson, K., \& Gretebeck, K. (2007). Factors influencing cancer screening practices of underserved women. Journal of the American Academy of Nurse Practitioners, 19, 11,591-601.

Adefuye, P., Broutet, N., Saanjoe. S., Denny, I. (2013). Trials and Projects on Cervical Cancer and Human Papillomavirus Prevention in Sub-Saharan Africa. Vaccine 31. 
Akinola, OI., Aimaku, CO., Ezechi, OC., Fasuba, OB. (2018). Society for Obstetrics and Gynaecology of Nigeria. Clinical practice guidelines: Guidelines for the prevention of cervical cancer. Trop J Obstet Gynaecol.32.371-376.

Alali, A., Salem, A.A., Elmahdi, H., Alkubaisi, N., Alwahedi, Z., \& Taher, M. (2016). Knowledge, Attitude of and practices regarding cervical cancer screening among female health care workers in primary healthcare in Qatar. The Middle East. East Fm Med. 14. 4-15

Albolfotouh, M.A., BaniMustafa, A.A., Mahfouz, A.A, Al-Assiri, M.H., Al_Juhani, A.F., \& Alaskar, A.S. (2015). Using the Health Belief Model to predict breast self-examination among Saudi Women. BMC Public Health, 15.1163.

Aldohaian, A.I., Alshammari, S.A., \& Arafah, D.A. (2019). Using the health belief model to assess belief and behaviours regarding cervical cancer screening among Saudi women: a cross-sectional observational study. BMC 19:6. https//doi.org/10.1186/s12905-018$0701-2$

Ampofo, A.G., Adumatta, A.D., Owusu, E., Awuviry-Newton, K. (2020). A Cross-Sectional Study of Barriers to Cervical Cancer Screening Uptake in Ghana: An Application of the Health Belief Model. Plus one 0231.459.

Anyebe, EE., Opaluwa, SA., Muktar, H. M., \& Philip, F. (2014). Knowledge and practice of cervical cancer screening amongst nurses in Ahmadu Bello University Teaching Hospital Zaria. Cancer, 4, 27.

Arevian, M., Noureddine, S., \& Kabakian T. (2006). Raising awareness and providing free screening improves cervical cancer screening among economically disadvantaged Lebanese/Armenian women. Journal of Transcult Nursing,17,357-365.

Arulogun, O.S., \& Maxwell, O.O. (2012). Perception and utilization of cervical cancer screening services among female nurses in University College Hospital, Ibadan, Nigeria. Pan African Medical Journal, 11, 69.

Audu, BM., El-Nafaty, AU., Khalil, M., \& Otubu, JAM., (1999) Knowledge and attitude of cervical cancer screening among women in Maiduguri. Journal of Obstetric Gynaecology 19,3,295-297

Awodele, O., Adeyomoye, A., Awodele, D., Kwashi, V., I. O. Awodele, I., \& Dolapo D. (2011). A study on cervical cancer screening amongst nurses in Lagos University Teaching Hospital, Lagos, Nigeria, Journal of Cancer Education, 26,3,497-504.

Awofeso, O., Roberts, A., Salako, O., Balogun, L., \& Okediji, P. (2018). Prevalence and Pattern of Late-Stage Presentation in Women with Breast and Cervical Cancers in Lagos University Teaching Hospital, Nigeria. Nigeria Medical Journal, 59,6,74-79.

Ayinde, OA., \& Omigodun, AO. (2003) Knowledge, attitude and practices related to prevention of cancer of the cervix among female health workers in Ibadan. Journal of Obstetric Gynaecology 23,1,59-62

Bray, F., Ferlay, J., Soerjomataram, I., Siegel, L., Torre, A., \& Jemal A. (2018). Global cancer statistics 2018: GLOBOCAN estimates of incidence and mortality worldwide for 36 cancers in 185 countries. CA: Cancer Journal for Clinicians, 68, 394-424.

Campos, N.G., Sharma, M., Clark, A., Jim, J.J., Resch, S.C. (2016). Resources required for cervical cancer screening in Low-and-Middle-Income Countries. ploS one, 11(10), e0164000.pmid:27711124.

Cancer-free coalition. Cervical cancer global crisis card. Assessed January 17, 2021

Catarino, R., Petignat, P., Dongui, G., \& Vassilakos, P (2015). Cervical cancer screening in developing countries at a crossroad: Emerging technologies and policy choices. World Journal Clinical Oncology,6,281-290. 
Cyril, C., Esther, E., Madubuko,T., Ngozi, R., \& Ezegwui, HU. (2009). Improved awareness of Pap smear may not affect its use in Nigeria: A case study of female medical practitioners in Enugu, South Eastern Nigeria. Transactions of the Royal Society of Tropical Medicine and Hygiene 103:852-854.

Dulla, D., Daka, D., \& Wakgari N. (2017). Knowledge about cervical cancer screening and its practice among female health care workers in south Ethiopia; a cross-sectional study. International Journal of Women's Health, 9, 365-372.

Eleanor B. \& Richmond R. (2018) Prevention of Cervical Cancer in Sub-Saharan Africa: The Advantages and Challenges of HPV Vaccination. Vaccines 6.61.10.3390

Elima, E.J., Maria, P.C., Olufemi, O., Emmanuel, O., Toyin, F., Festus, I. (2012) Cancer incidence in Nigeria: a report from population-based cancer registries. Cancer Epidemiology 36.5.271-278

Eze, J., Umeora, U., Obuna, J., Egwuatu, V., \& Ejikeme, B (2012). Cervical cancer awareness and cervical screening uptake at the Mater Misericordiae Hospital, Afikpo, Southeast Nigeria," Annals of African Medicine, 11,4, 238-243.

Eze, JN., Emeka-Irem, EN., \& Edegbe, FO. (2013). A six-year study of the clinical presentation of cervical cancer and the management challenges encountered at a state teaching hospital in southeast Nigeria. Clinical Medical Insights Oncology,7,151-158

Ezem, BU. (2007). Awareness and uptake of cervical cancer screening in Owerri, SouthEastern Nigeria. Annals African Medicine 6,3,94-98

Ezeome, ER. (2010). Delays in presentation and treatment of breast cancer in Enugu, Nigeria. Nigeria Journal of Clinical Practice, 13,311-316

Fernández, J, Rodrigues, S., Silva da Costa., Y., Moura da Silva., L., Lima de Brito., A., Veríssimo de Azevedo, J., Duarte do Nascimento, E., Medeiros de Azevedo., PR \& Thales., A. (2009). Knowledge, attitudes, and practices related to Pap test in NorthEastern. Brazil. Rev Saúde Pública 43(5):851-858.

Glanz, K., Rimer, B., \& Vismanath, K. (2008). Health behaviour and health education theory, research, and practice (4th ed.). USA: Jossey Bass.

Guintoli, R., Bristow, R. (2008). Cervical cancer. In RS Gibbs et al., eds., Danforth's Obstetrics and Gynecology 10th ed, pp. 971-988. Philadelphia: Lippincott Williams and Wilkins.

Heena, H., Durrani, S., ALFayyad, I., Riaz, M., Tabasim, R., Parez, G., \& Abu-Shaheen, A. (2019) Knowledge, Attitudes and Practices towards Cervical Cancer and screening among female health professionals: A cross-sectional study. Journal of oncology. 1155.5423130

Kalkidan, S., Mulugeta, T., \& Mirgissa., K. (2019). Predictors of Cervical Cancer Screening Practices among HIV positive Women attending adult Anti-retroviral Treatment Clinics in Bishoftu town, Ethiopia: the application of a Health Belief Model. BMC. 19.989/1288.019-6171-6.

Koliopoulos, G., Nyaga, VN., Santesso, N., Bryant, A., Martin-Hirsch, PP., Mustafa, RA., et al. (2017). Cytology versus HPV testing for cervical cancer screening in the general population. Cochrane Database Systematic Review: CD008587

Liao, CC, Wang, HY, Lin, RS, Hsieh, CY \& Sunga, FC. (2006). Addressing Taiwan's high incidence of cervical cancer: Factors associated with the Nation's low compliance with Papanicolaou screening in Taiwan. Public Health 120:1170-1176.

Ma, GX., Gao, W., Fang, CY., Tan, Y., Feng, Z., Ge, S., \& Nguyen, JA. (2013). Health beliefs associated with cervical cancer screening among Vietnamese Americans. Journal of Women's Health, 22(3), 276-288. 
Mandelblatt, JS. (1999) Is HIV infection a cofactor for cervical squamous cell neoplasia? Cancer Epidemiology Biomark Preview, 8,97-106.

Mbachu, C., Dim, C., \& Ezeoke, C., (2017). Effects of peer health education on perception and practice of screening for cervical cancer among urban residential women in southeast Nigeria. A before and after study. British Medical journal women's health. 17.14.0399-6.

Momenimovahed, Z., \& Salehiniya, H. (2017). Incidence, mortality and risk factors of cervical cancer in the world. Biomedical Research and 2erapy, 4, 12, 1795-1811.

Moscicki, AB., Shiboski, S., Hills, NK., Powell, KJ., Jay, N., \& Hanson, E.N. (2004). Regression of low grade squamous intraepithelial lesions in young women. Lancet 364:1678 -1683

Mugenda O.M., \& Mugenda A.G. (2003). Research methods: Qualitative and Qualitative approaches. Nairobi: ACTS Press.

Mutyaba, T., Mmiro, F., \& Weiderpass, E. (2006). Knowledge, attitudes and practices on cervical cancer screening among the medical workers of Mulago Hospital, Uganda. BMC Medical Education.

Narayana, G., Suchitra, M., Sunanda G., Ramaiah, J., Kumar, B., \& Veerabhadrappa, K. (2017). Knowledge, attitude, and practice toward cervical cancer among women attending obstetrics and gynaecology department: a cross-sectional, hospital-based survey in South India. Indian Journal of Cancer, 54, 2, 481-487.

Nwobodo, E., \& Malami, A (2005). Knowledge and practice of cervical screening among female health workers in Sokoto, North-Western Nigerian. Postgraduate Medical Journal, 12, 4, 255-257.

Nwobodo, EI., \& Malami, SA. (2005). Knowledge and practice of cervical screening among female health workers in Sokoto, North-Western Nigeria. Nigerian Postgraduate Medical Journal, 12, 4, 255-257.

Nwozor, M., \& Oragudosi, L. (2013). Awareness and Uptake of Cervical Cancer Screening among Women in Onitsha, South-East, Nigeria. Greener Journal of Medical Sciences, 3, 8,283-288.

Nyaberi, Z., Were, E., \& Buziba, N. (2011). Perceptions of risk and barriers to cervical cancer screening at Moi Teaching and Referral Hospital (MTRH), Eldoret, Kenya. African Health Sciences 11:58-64.

Nygård M. Screening for cervical cancer (2011). When theory meets reality. BMC Cancer, 11, 240.

Oche, MO., Kaoje, AU., Gana, G \& Ango, JT. (2013). Cancer of the cervix and cervical screening: Current knowledge, attitude and practices of female health workers in Sokoto, Nigeria. International Journal of Medicine and medical science, 5, 4, 185-190.

Oludotun, T., Odukoya, OO, \& Balogun, MR., (2019). Knowledge, Attitude and Practice of cervical cancer prevention among women residing in an urban slum in Lagos, South West, Nigeria. Pan African Medical Journal. 32.130.14432

Oluwole, EO., Mohammed, AS., Akinyinka, MR., \& Salako O. (2017). Cervical cancer awareness and screening uptake among rural women in Lagos, Nigeria. Journal of Community Medical Primary Health Care, 29,81-88.

Onyenwenyi, AO., \& Gugu GM. (2016). Strategies for the prevention and control of cervical cancer in rural communities: A Nigerian perspective. Journal of Community Medicine, Prim Health Care, 28,77-93. 
Poli, U.R., Bidinger, P.D., \& Gowrishankar, S. (2015). Visual Inspection With Acetic Acid Via Screening Programme; 7years Experience in Early Detection of Cervical Cancer and Pre-Cancers in Rural South India. Journal of community medicine 40. (3).203 -207

Riaz, L., Manazir, S., Jawed, F., Arshad Ali, S., \& Riaz, R. (2020). Knowledge, Perception, and Prevention Practices related to human Papillomavirus-based Cervical Cancer and its Socioeconomic Correlates among women in Karachi, Pakistan. Cureus. DOI 12.3.10.7759.7183

Sankaranarayanan, R., Budukh, A.M., \& Rajkumar, R. (2001). Effective screening programmes for cervical cancer in low- and middle-income developing countries. Bull World Health Organization, 79(10):954-962.

Shekhar S, Sharma C, Thakur S, Raina N. (2013). Cervical cancer screening: Knowledge, attitude and practices among nursing staff in a tertiary level teaching institution of rural India. Asian Pacific Journal Cancer Prevention. 14,3641-5

Singh, S \& Badaya, S. (2012). Factors influencing uptake of cervical cancer screening among women in India: A hospital-based pilot study. Journal of Community Medical Health Education 2:157-164.

Sowemimo, OO., Ojo, OO., \& Fasubaa, OB. (2017). Cervical cancer screening and practice in low resource countries: Nigeria as a case study. Tropical Journal of Obstetrics Gynaecology, 34,170-176.

The Global Cancer Observatory (2020): GLOBOCAN 2020 Nigeria Population and Cancer Fact Sheet. https://gco.iarc.fr/today/data/factsheets/populations/566-nigeria-factsheets.pdf

Udigwe, GO. (2006). Knowledge, attitude and practice of cervical cancer screening (pap smear) among female nurses in Nnewi, South Eastern Nigeria. Nigeria Journal of Clinical Practice, 9 1, 40-43.

Umukoro, C. E., \& Makinde, O. Y. (2019). Perspectives of visual inspection of the cervix with acetic acid as an alternative to Pap smear test as a preventive measure of cervical cancer among female nurses in University College Hospital, Ibadan, Nigeria. Journal of Cancer Research and Practice, 6(1), 18.

Urasa M. \& Darj E. (2011). Knowledge of cervical cancer and screening practices of nurses at a regional hospital in Tanzania. Africa Health Science, 11 (1):48 - 57

World Health Organization (2013). WHO Guidelines for Screening and Treatment of Precancerous Lesions for Cervical Cancer Prevention. Geneva: World Health Organization; 1-40.

Wright, K.O., Aiyedehin, O., Akinyinka, M.R., \& Ilozumba, O. (2014). Cervical Cancer: Community Perception and Preventive Practices in an Urban Neighbourhood of Lagos. Nigeria. Journal of preventive medicine.10.1155.950534.

Yakout, S.M., Moawed, S., \& Gemeay, E.M. (2019). Cervical Cancer and Screening test (PAP TEST): Knowledge and Belief of Egyptian women. Am J Nurs Sci. 2016.5.17584.

Yu, FQ., Murugiah, MK., Khan, AH., \& Mehmood, T. (2015). Meta-synthesis exploring barriers to health-seeking behaviour among Malaysian breast Cancer patients. Asian Pacific Journal Cancer Prevention, 16,1,145-52.

Zheng Hu. \& Ding Ma. (2018). The Precision Prevention and therapy of HPV-related cervical cancer: new concepts and clinical implications. cancer medicine. 7(10):52175236. Doi:10.1002/cam4.1501. 